\title{
Gereformeerde mistiek en die neerslag daarvan in piëtistiese ego-tekste van manlike gelowiges in die Suid-Afrikaanse pionierslewe
}

\author{
Author: \\ Andries W.G. Raath ${ }^{1}$ \\ Affiliation: \\ ${ }^{1}$ Department of \\ Constitutional Law, University \\ of the Free State, \\ South Africa \\ Correspondence to: \\ Andries Raath \\ Email: \\ raatha@ufs.ac.za \\ Postal address: \\ PO Box 339, Bloemfontein \\ 9301, South Africa \\ Dates: \\ Received: 27 June 2011 \\ Accepted: 05 Feb. 2012 \\ Published: 13 July 2012 \\ How to cite this article: \\ Raath, A.W.G., 2012, \\ 'Gereformeerde mistiek \\ en die neerslag daarvan \\ in piëtistiese ego-tekste \\ van manlike gelowiges \\ in die Suid-Afrikaanse \\ pionierslewe', HTS Teologiese \\ Studies/Theological Studies \\ 68(1), Art. \#1123, 9 pages. \\ http://dx.doi.org/10.4102/ \\ hts.v68i1.1123
}

C 2012. The Authors.

Licensee: AOSIS

OpenJournals. This work

is licensed under the

Creative Commons

Attribution License.
Reformed mysticism and the culmination thereof in pietistic ego-texts of male believers in the South African pioneer life on the frontier. The manifestation of Reformed mysticism in the pioneering communities of the South African interior was not limited to women-believers only. Although less frequent, Reformed mysticism contained in the pietistic ego-texts of male-believers also surfaced in early pioneering communities of South Africa. This essay considers the mystical ego-text of Francois Retief (1773-1838), the brother of Piet Retief who was massacred with other Voortrekkers by the Zulu king Dingaan in February 1838. Francois Retief's ego-text reflects typical elements of Jesus-centred bridal mysticism. Although it does not contain the radical features of bridal mysticism prevalent among women-believers on the frontier, it reflects intense levels of spiritual consciousness associated with the energetic levels of faith among Reformed believers under dire circumstances on the frontier.

\section{Inleiding}

Fred van Lieburg se Levens van vromen: Gereformeerd piëtisme in de achtiende eeuw (1991) maak 'n belangrike bydrae tot die verstaan en waardering van die inslag van die gereformeerde piëtisme in agtiende-eeuse Nederland. Van Lieburg toon aan dat die gereformeerde piëtisme in die 17de en 18de eeu sterk in Nederlandse gereformeerde kringe teenwoordig was. Mahrholtz (1919) beskryf die opkoms van die piëtisme en die kultuur van outobiografiese ego-tekste in dié kringe as manifestasies van die Christelike mistiek:

Was war nun der Pietismus? Wenn man es sehr weit fassen will, nichts anderes, als eine energische Reaktion gegen die Mechanisierung und Intellektualisierung der protestantischen Kirche und ein Zurückgreifen auf die seit Ekkeharts Tagen niemals ganz abgerissene Tradition der deutschen Mystik. (bl. 143)

Teen die agtergrond van die inslag van die gereformeerde mistiek in die Nadere Reformasie van die 17de en 18de eeu, is veral twee aspekte van Van Lieburg se werk met die oog op die bepaling van die omvang en diepte van die mistieke piëtisme in die pioniersgemeenskappe van die Nederlandse moederland en die Suid-Afrikaanse binneland van besondere belang: eerstens die bestaan van wat in 'n Nederlandse konteks die 'volkspiëtisme', binne die Christelik-mistieke tradisie, genoem kan word ${ }^{1}$; tweedens die vraag tot welke mate mistieke ego-tekste met piëtistiese inslag as verteenwoordigend van 'n bepaalde 'godsdienskultuur' onder sowel mans as vroue op die voorposte van die Suid-Afrikaanse binneland beskryf sou kon word.

In verskeie Suid-Afrikaanse publikasies het aspekte wat met hierdie vrae verband hou ter sprake gekom. In sy artikel ‘Vroeë Geskrifte deur Suid-Afrikaanse Vroue, 1749-1865' het Karel Schoeman (1995) byvoorbeeld aangetoon dat die outobiografieë, dagboeke, sterfbed-relase, briewe en gedigte van Nederlandsprekende vroue in Suid-Afrika in die vroeë Kaapse volksplanting ' $n$ bepaalde neiging tot die piëtisme verraai en - selfs belangriker - as die begin van geskrewe SuidAfrikaanse literatuur beskryf kan word. Dit op sigself maak die verskynsel van die piëtisme 'n onderwerp wat met die oog op die sosiale, kulturele, politieke en godsdienstige peiling van die heersende sentiment onder Nederlandssprekendes op die grense van die Suid-Afrikaanse binneland belangrik is.

Navorsing oor die omvang van die gereformeerde piëtisme in die Kaapse binneland word egter deur verskeie aspekte bemoeilik: eerstens die beskikbaarheid van ego-tekste uit die tradisie van die vroeë Kaapse piëtisme; tweedens die komplekse invloede wat op een of ander wyse 'n bydrae tot die ontstaan van 'n tradisie van gereformeerde mistiek in die Suid-Afrikaanse binneland bygedra het, en derdens die vraag tot welke mate geskrifte uit die genre van die gereformeerde 1.Kyk Van Lieburg (1991:187-189). Die neiging tot onderskeid van die massas; die hou van huisgodsdiensoefeninge; die saamkom in konventikels; gereelde kerkgang met ' $n$ uitgesproke voorkeur vir bevindelike predikante; die dra van sober, nie-modieuse klere; die veelvuldige lees van die Bybel en stigtelike lektuur en ' $n$ onderskeidende taalgebruik. 
volkspiëtisme as aanduiding van 'n invloedryke tendens in die Suid-Afrikaanse geloofsgeskiedenis beskou kan word.

'n Studie van die inslag van die gereformeerde piëtisme in die Kaapse binneland moet met twee belangrike aspekte rekening hou: eerstens, dat die piëtisme as sodanig op sy beurt die uitvloeisel van ' $n$ meer 'universele' tendens van Christelike mistiek in die Westerse godsdiensgeskiedenis was; tweedens, dat die gereformeerde piëtisme nie slegs tot vrouepersone beperk was nie, maar ook onder seuns en manspersone voorgekom het. Om hierdie redes is ' $n$ oorsig oor die Christelike mistiek in die Westerse godsdiensgeskiedenis en 'n analise van piëtistiese geskrifte deur manspersone in die genre van mistiek-volkspiëtistiese werke van besondere belang.

\section{Christelike mistiek en gereformeerde piëtisme in die Westerse godsdiensgeskiedenis Middeleeuse wortels van die Christelike mistiek in die Westerse wêreld}

Reeds in die vroeë Christelike gemeenskappe van die tweede eeu na Christus, het skrywers begrip gevra vir die mistieke toegang tot God deur 'n studie van die Woord en toegewyde bepeinsing. Origine van Alexandrië (c. 185 - c. 254) het veral die mistieke toegang tot God deur 'n studie van die Woord en afgesonderde oordenking beklemtoon. Binne dié godsdienstige konteks verkry die term mystikos die spesifieke betekenis van die verborge nadering tot God (kyk McGinn 1991:vi, xvi, 108 e.v.). Deur Dionisius se propagering van die mistieke geloofsbeoefening (McGinn 1991:146)² en Evagrius Ponticus (345-399) se beklemtoning van die toegewyde nadenke in die Christelike geloofspraktyk, het Ambrosius van Milaan (c. 340-397) en Augustinus (354-430) die mistiek as ' $n$ blywende deel van die Christelike godsdiens gevestig. ${ }^{3}$ Die werk van sowel Origine as Augustinus het die Christelike mistiek as 'n omvattende proses of lewenswyse, eerder as ' $n$ enkele ervaring of insidentele vereniging met God gevestig (McGinn 1994:xi, xii). ${ }^{4}$

Van die belangrikste bronne waaruit Augustinus, met die oog op sy beklemtoning van die mistieke kennis van die Woord geput het, was die Griekse filosoof Plato (428/427-348/347 v.C.) se onderskeid tussen die wêreld van beelde en die wêreld van vorms (of idees); tussen doxa [opinie] en episteme [ware kennis]; tussen tydelikheid en onveranderlike ewigheid.

2.Veral opvallend is sy asketiese ingesteldheid. Hy onderskei drie aspekte van die mistieke lewenshouding: asketiese leefstyl, kontemplasie van die fisiese wêreld en kontemplasie van God. Volgens McGinn (1991:158) was hy die skepper van die term mistieke teologie.

3.Vir Ambrosius se bydrae tot die Christelike mistiek kyk McGinn (1991:203). Hy handhaaf ' $n$ sintese van Christelike dogma en neo-Platonisme; die Bybelboek Hooglied vorm die middelpunt van sy kerklike mistiek; hy propageer die ideaal van maagdelikheid as mistieke deug veral in sy werke De Virginibus (377) en De Virginitate (393).

4.Die apokaliptiese literatuur van die Joodse mistici het ook ' $n$ sterk invloed in dié verband laat geld. In Die Testament van Levi word visionêre drome beskryf waarin die patriarg hem. die patriarg hemelwarts 'n gees van insig ('spirit of understanding') wat 'A hom in staat stel om die vervalle sedelike toestand van sy volk te deurgrond. "(A)nd I saw all men corrupting thei way, and that unrighteousness had built for itself walls, and lawlessness sat upon towers' (Crane 1974:226-233).
Deur dié teenstellings het Plato gepoog om die spanning tussen die onvermydelike nabyheid van verborge kennis en die afstand wat God op die skepping handhaaf, te oorbrug. Volgens Plato is nadenke (kontemplasie) deur die 'afskouing' van alle tydelike en wisselende beelde die wyse waarop die menslike gees of intellek (die nous) die terreine van tyd en ewigheid kan verenig deur die intellek se intuïtiewe kontak met die Absolute Godheid. Die menslike intellek funksioneer as't ware as ' $n$ 'goddelike banneling' wat tydelikhede en onveranderlike onsterflikheid deur middel van nadenke met mekaar verenig (kyk McGinn 1991:24-26); deur die nous se intuitiewe kontak met die Absolute word die spanning tussen tydelikheid en onveranderlike onsterflikheid oorbrug. In die mistieke lyne wat deur Augustinus se benadering tot die mistiek beïnvloed is, kan die mistiek in die wydste sin as die transformasie van die bewustelike deur meditasie beskryf word. ${ }^{5}$

In die vernaamste tradisies van die Christelike mistiek wat in die tydperk van die laat-Middeleeue na vore getree het, het die klem op bepeinsing en introspeksie 'n vername bestanddeel van die mistieke geloofspraktyke gevorm: eerstens op die 'filosofiese' mistiek in die lyn van Eckhart en Tauler; tweedens op die rigting van die bruidsmistiek wat deur Origine en Bernard van Clairvaux geïnisieer is, en derdens op die mistieke rigtings wat elemente van sowel die 'filosofiese' as die bruidsmistiek vertoon het.

Die filosofiese mistiek met die meegaande klem op die verwerwing van ware kennis het in die Christelike mistieke tradisie in Duitsland deur die werke van Meister Eckhart (Johannes 'Meister' Eckhart, c. 1260-1327) en sy navolger Johannes Tauler (c. 1330-1361) 'n groot en blywende invloed gehad. Die inslag van Meister Eckhart se mistiek is herlewing (teogenese), oftewel die 'tweede geboorte' met die gevolglike verwerwing van ware saligmakende kennis (Schürmann 2001:17). Die mistieke herlewing vind plaas in die sielegrond van die menslike intellek'; die grond van die siel is ' $n$ krag in die menslike gees wat bo tyd en verganklikheid uitstyg. Dié krag in die menslike gees is ' $n$ 'lig' in die intellek. Ten einde die Woord te ontvang moet die intellek ontdaan wees van alles wat tydelik is en 'bevry' wees van alle beelde en sintuiglikverworwe kennis. Die menslike siel is in staat om tot die ware kennis van die menslike 'wedergeboorte' (oftewel teogenese) in die grond van die siel te kom omdat dit tussen tyd en ewigheid geskape is. Die loswring (Abgeschiedenheit) van tydelikheid (hetsy as beelde of as sintuiglike kennis) is die voorbereiding van die siel vir die oopstelling (Gelassenheit) vir die Woord. ${ }^{7}$ Leegheid of 'maagdelikheid' is die eerste voorwaarde vir die mistieke ontmoeting met die Woord in die sielegrond van die mens. Deur die afwending van alle

$5 . V i r$ 'n uitvoerige ondersoek na die verskillende komponente van die Christelike mistiek, sien De Reuver (1997:1-54); De Niet (1997:55-66) en Langelaar (1997:67-76).

6.Eckhart onderskei tussen die intellek en die grond van die intellek: die gemüete [die intellek] kyk 'skouend' terug in die hart (oftewel siel), teenoor die rede wat 'uitwaarts' gekeer is.

7.'Abgeschiedenheit' [geestelike afskouing] is die hoogste deug. dit dwing ons om Gods werk in liefde waar te neem (Campbell \& Zaleski 1991:107). Kyk ook Campbell en Zaleski (1991:71): 'A pure heart is one that is unencumbered, unworried, uncommitted, and which does not want its own way about anything but which, rather, is submerged in the loving will of God, having denied self.' 
tydelike dinge (indrukke), word die intellek in staat gestel om die idees van kennis wat potensieel in die menslike gees teenwoordig is, tot uiting te bring. Die 'geboorte' van die Woord in die grond van die siel, is terselfdertyd ook ' $n$ eenwording met God. ${ }^{8}$ Vir dié éénwording is dit nodig dat die geestelike (oftewel innerlike) 'oog' op God gerig moet wees, omdat die eksterne oog van die mens, daarenteen, slegs in staat is om eksterne indrukke te versamel. ${ }^{9}$

Meister Eckhart se student, Johann Tauler (c. 1330-1361), het sy leermeester se klem op 'afskoue' en 'vereniging' in die proses om tot ware sielskennis te kom, van 'n stewiger teologiese grondslag voorsien. Tauler laat die klem veral op die innerlike beeld van God in die sielegrond van die mens val. Soortgelyk as sy leermeester, het Tauler ook die standpunt gehandhaaf dat die afskoue van alle tydelikheid 'n belangrike voorwaarde vir die oopstelling vir die geboorte van die Woord in die diepste wese van die mens vorm. ${ }^{10}$

In verskeie opsigte het die tradisie van bruidsmistiek 'n sterker effek op die Christelike godsdienskultuur van Europa uitgeoefen. Bernard van Clairvaux (1090-1153) het nie soseer kennis as einddoel van die mistieke praktyk vooropgestel nie, maar wel die mistieke vereniging met God as sodanig. Die drie stadia waardeur die siel tot ekstatiese vereniging met God kom, is dié van purifikasie [suiwering], illuminasie [verligting] en kontemplasie [nadenke]. Ten einde tot die vereniging met God te kom en dit deur ekstatiese visioene te beleef, moet die menslike siel sigself volkome in God 'verloor' en die totale menslike persoon in die Ewige versink; soos die lug wat van die son se lig vol is, in dieselfde heerlikheid verander word, sodat dit nie langer verlig word nie, maar self lig is, moet elke menslike geesteskrag ontbind word en in die wil van God verander word. God sal slegs alles in almal wees indien niks mensliks in die menslike wil oorbly nie (McGinn 1998:170 e.v.).

Bernard se klem op die menslike nadenke in die proses van eenwording met God, het aan die geneigdheid tot afsondering (asketisme) onder Christen-mistici 'n kragtige hupstoot gegee. Die element van vereniging met God en die ekstatiese belewing daarvan deur middel van visioene, het in die bruidsmistiek van die Middeleeuse vroue-mistici tot 'n sterk tradisie ontwikkel. Mechthild van Magdeburg (1240-1298) het veral daartoe bygedra om die bruidsmistiek een van die sterkste godsdienstige tradisies van die Middeleeue te maak (McGinn 1998:32 e.v.). Die eenwording met Christus gaan ook gepaard met die liefdevolle oordrag van kennis, wat die 'ontvanger' se denke en lewenspatroon verander. Die visioene wat met die ontvangs van die verborge kennis plaasvind, is hoofsaaklik 'visualiserings' in die vorm van kragtige denkbeelde oor en voorstellings van Christus.

Onder invloed van Thomas à Kempis (c. 1380-1471) se werk Navolging van Christus, het die Christelike mistiek in die 8.Volgens Campbell en Zaleski (1991:93, 136 e.v).

9.Die volkome 'losmaak' van alle geskapenes is die hoogste vryheid (Cambell \& Zaleski 1991:108)

10.Kyk Eckhart (2009:135-136) en Tauler (1961:6, 40). geledere van vroeë reformatore soos Luther, Melanchthon en Calvyn, wyd inslag gehad. À Kempis het veral die klem op afsondering en eensame oorpeinsing as prysenswaardige opofferinge laat val. ${ }^{11}$ À Kempis verklaar prontuit dat toegewyde Christene die eensaamheid moet opsoek en deur asketiese afsondering hul tot die stilte moet wend. In À Kempis se ander werke Eenige Tractatjens, Het Hofken der Roosen en Het Dal der Lelien (1680) ${ }^{12}$ het hy eweneens die asketiese afsondering aangeprys. ${ }^{13}$

\section{Christelike mistiek en die Nadere Reformasie Mistiek-piëtistiese ego-tekste in Nederland}

Die filosofiese mistiek van Meister Eckhart en Johannes Tauler, het veral deur middel van die Duitse piëtistiese godsdienstige werke na die Kaap gekom. Die bruidsmistiek en die asketiese mistiek van À Kempis het op hul beurt 'n sterk invloed op die gevoelsmatige godsdienstige beskouings van die outeurs van die Nadere Reformasie in Nederland gehad. Die Nadere Reformasie met die meegaande oplewing in gereformeerd-piëtistiese werke, het veral in Nederland wel deeglik vanaf die $17 \mathrm{de}$ tot die 19 de eeu 'n geestelike wending vanaf die meer rasioneel-georiënteerde tradisionele Calvinisme tot die beklemtoning van die bevindelike sielekennis en die kommunikasie daarvan in klein groepies gelykgesinde sogenaamde 'konventikel'-gangers tot gevolg gehad. ${ }^{14}$ Veral die piëtistiese mistiek het spreekwoordelik van die gereformeerde Nederlandse geesteswêreld geword. Met die oog op die kommunikasie van mistieke en bevindelike ervarings in die kringe van gelykgesindes, het die neerskryf van godsdienstige ego-tekste wyd voorgekom. ${ }^{15}$ Gereformeerde mans en vroue het die vervalle politieke, sedelike en godsdienstige toestande in Nederland, soos hulle dit gesien het, betreur en hul harte in versugtinge van toekomstige geestelike en politieke verlossing uitgestort.

Die piëtis Willem Mense skets in 'n gedig die treurige toestand van Nederland op politieke en godsdienstige gebied vergeleke met die ontstaansgeskiedenis van Nederland toe die Republiek van Spaanse dwingelandy en afgodiese beelde en altare bevry is; soos God eens die volk Israel van die juk van die Egiptenare bevry het, het hy ook die verdrukte Nederlandse volk in vroeër tye geseën (1877:89-91).

In sy pessimisme oor die geestelike welsyn van die vaderland, stort Adriaan van de Roestijne (1712-1779) in sy lewensrelaas

11.Kyk byvoorbeeld 1687:41 (hfst. XVil) en 1687:51 (hfst. XX: Van de Liefde des eensaamheyds ende stilte)

12. Het Dal der Lelien, hfst. XXIX.

13.Volgens ook 1680 (D'Aleensprake der Ziele, hfst. XIII). À Kempis het' $n$ groot invloed op die Nederlandse Nadere Reformasie uitgeoefen, kyk Op 't Hof (1987:151 e.v.); Van 't Spijker $(1989: 45,49)$.

14. Dit neem nie daarvan weg dat sommige reformatore ook' $n$ sterk geneigdheid tot die mistiek gehad het nie, kyk Brienen (1978:58, 59 e.v.). Vir die inslag van die konventikel-kultuur in die Suid-Afrikaanse binneland, kyk Raath (2003:121-150, 131).

15.Die mistieke piëtis Hermanus Hermsen (1696-1786) is'n sprekende voorbeeld van die kultuur om ego-tekste van mistieke sielservarings te publiseer (kyk Hermsen 1757). Hermsen se boekie is wyd gelees. Ds. Michiel Christiaan Vos (1759-1826) in mistiek-piëtistiese predikant berig van die Kaap dat die werk ook daar gelees is (Van Lieburg 1991:169). Ander outeurs in dié kaders was o.a. Johannes van is $(V a n$ Lieburg 1991:169). Ander outeurs in die kaders was o.a. Johannes van
Diesbach (1715-1793) (1770); Cornelis de Korte (1733-1798) (1781); en Geesjen Pamans (1727-1821) (1775) (kyk Van Lieburg 1991:150-156). 
sy smart oor talle volkseuwels uit: hoogmoed en weelde bepaal die kultuur en mode; ontug word in alle lae van die samelewing deur getroudes en ongetroudes beoefen; vloek en sweer, lis en bedrog, diefstal en goddelose spele is aan die orde van die dag, terwyl die onderskeid tussen ware en valse godsdienste - met name die gereformeerde en die Roomse toenemend vervaag. Die outeur kla selfs dat indien daar nie 'n geestelike wending sou plaasvind nie, God se seën uit kerk en staat sou wyk (1766:69). ${ }^{16}$

Eva van der Groe (1704-1770) skryf 'n uitvoerige verslag oor haar geloofsbelewenisse omtrent 'dat eertijds zoo gezegend Nederland, gedurende den tijd van acht jaren, waarin hetzelve door zeer gedruckt, verwoest en vervreemd is geworden' (1838:69). In dieselfde lyn getuig Jan Fokkert (1721-1792) in die jaar 1776, aan die sterfbed van sy 22-jarige seun, hoe die Here hom twee jaar tevore op 'n biddag laat 'sien' het watter bittere dae die Here oor die Nederlandse volk en kerk, vanweë hul sonde en ongeregtigheid, sou bring (Van Lieburg 1991:152-153).

In die kringe van die mistiek-bevindelike gereformeerdes was buitengewone geestelike ervarings soos visioene ('voorgezichten') van straf en stryd, drome en geestelike vervoeringe, nie vreemd nie. Die Smid van Grijpskerke 'ervaar' die tekens aan die hemel as voorspellings van gebeure wat op soortgelyke wyse voor die verwoesting van Jerusalem waargeneem is (De Korte 1781:16-17). Willem Bijl ontvang ' $n$ visioen terwyl hy op sy bed lê van 'in het noorden een draak, met twee lamsooren, en een driekant peil in den mond als een harpoen.' $\mathrm{Na}$ 'n gebed openbaar die Here aan Bijl die betekenis van die gesig: die draak is die duiwel wat die aarde besoek om die mense te verlei, 'en dit gezicht geschiedde in dien tijd toe de Franschen byna over de geheele aarde verspreid waren', 'n tydstip toe ook die Nederlandse volk vanweë sy ongodsdienstigheid, losbandigheid en ligsinnigheid beproef is (Bijl 1981:37-38). ${ }^{17}$

\section{Mistiek-godsdienstige lektuur van die Nadere Reformasie}

Werke van skrywers soos Henricus Ravesteyn (1692-1749) ${ }^{18}$, Jodocus van Lodenstein (1620-1677; kyk Proost 1880), Bernardus Smijtegelt (1665-1739)19; Wilhelmus à Brakel $(1635-1711)^{20}$ en Alexander Comrie (1706-1774) $)^{21}$ was in bykans elke Boerehuis op die Kaapse grense en in die latere republieke van die Transvaal en die Oranje-Vrystaat te

16.Tot eer van God en ter gedagtenis van Adriaan van de Roestijne, geboren te Westersouburg den 16 december 1712, overleden den .... [nie ingevul] en te Westersouburg begraven den 28 April 1779, (1766:45-51).

17.Paulus van der Spek (1723-1809) (1850) skryf oor die onderwerping van die Nederlandse volk aan 'n vreemde oorheerser as Gods oordele oor kerk en staat. Kyk ook die lang relaas van Egbert de Goede oor die nasionale oordele wat die Nederlandse volk getref het en waarvan hy persoonlik'n getuie was (1868:56-57; $58-62)$.

18.Veral belangrik is sy $1746: 128$ e.v.

19.Let veral op sy Des Christens Heil en Cieraat (1740).

20.Redelijke Godsdienst, (1726). Ook die werk van Petrus Broes (1904), Peinzende Christen, kan tot hierdie werke gereken word.

21.Kyk veral Heppe (1879). Vir Lodenstein kyk Proost (1880:143-144). Proost voeg by dat Lodenstein se mistiek die volgende elemente bevat: die goddelike volmaaktheid, die geringskatting van die rede, die askese en selfverloëning. vinde. ${ }^{22}$ Dié sogenaamde 'Oude Schrijvers' se werke is met toewyding en entoesiasme gelees. Geestelike afsondering, die bevinding van die geloof en die oopheid vir mistieke 'buite-natuurlike' geesteservarings, het 'n wesenlike element van die preekbundels, godsdienstige oordenkingsboeke en ander godsdienstige literatuur gevorm. Drome, visioene en buitengewone geestelike ervarings was nie vreemde onderwerpe in die werke van die skrywers in dié kader nie. In baie gevalle is die preke, oordenkings en stigtelike relase van die Oude Schrijvers 'stenografies', met ander woorde deur toehoorders, opgeteken, wat deur die inhoud daarvan geestelik geroer of gemotiveer is.

In een van die mees populêre werke uit die tyd van die Nadere Reformasie, Abraham Hellenbroek se Kruis Triomph van Vorst Messias (1745), gebruik hy die verwysings na die droom van Pilatus se vrou in die Nuwe Testament op so 'n wyse dat hy die punt tuisbring dat drome in die vroeë oggend méér geloofwaardig is omdat die menslike brein dan van die meeste skadelike invloede bevry is (1745:401 e.v.).

John Newton se werk Gods Genade en Vrijmagtig Albestuur (1764) gee ' $n$ uitgebreide beskrywing van buitengewone drome wat hy gehad het en wat ' $n$ dramatiese invloed op sy lewe gehad het. Hy voeg by dat drome ter waarskuwing aan die ontvanger daarvan gegee word. Vervolgens beskryf Newton sy droom: hy staan alleen op die dek van 'n skip in Venesië waar 'n persoon aan hom 'n ring gee om tot sy eie beswil te bewaar. Kort daarna word hy deur ' $n$ ander persoon gekonfronteer wat hom daarvan oortuig om die ring in die see te gooi, waarna ' $n$ verskriklike vuur uit die Alpiese berge opstyg. Tot sy ontsteltenis moes Newton verneem dat dit vlamme vanweë sy eie ongehoorsaamheid was. Op die punt om na die verderf te gaan, verskyn die eerste persoon weer aan Newton. Ná belydenis van sy dwaasheid, besorg die eerste persoon weer die verlore ring aan Newton; meteens word die vlamme op die berge uitgedoof en word Newton se vrees en angs tot 'n einde gebring (1764:33 e.v., 37).

\section{Die neerslag van die mistieke piëtisme aan die Kaapse volksplanting van die 18 de en 19de eeu Die kultuur van mistieke piëtisme onder gelowiges in die binneland}

Die fisieke afsondering van die Boerepioniers in die binneland en hul bestudering van die godsdienstige literatuur van die Nadere Reformasie ${ }^{23}$ het 'n pionier-etos onder die binnelandse grenspioniers tot gevolg gehad wat eksplisiete Christelik-

22.Veral $\ddot{A}$ Brakel is wyd gelees. A Brakel het veral A Kempis se oproep tot eensame afsondering gepropageer (A Brakel 1726:496). À Brakel doen 'n ernstige beroep in dié verband: 'Wel aen dan kinderen Godts/zoekt het aengezigte uwes Vaders in het verborgene/neemt somtijds tijd/en zoekt eensame plaetsen/om daer te worstelen/te bidden/te schreyen/te roepen/te wagten op de vertroostingen des Heeren; ...

23.Verstaan as die beweging binne die Nederduitse Gereformeerde Kerk in die sewentiende en agtiende eeu, wat in reaksie op die verflouing van of' $n$ gebrek aan lewende geloof, die persoonlike geloofsbelewing en godsvrug sentraal stel en van daaruit inhoudelike en prosedurele reformasieprogramme opstel, by die bevoegde kerklike, politieke en maatskaplike organe indien en/of in aansluiting daarby self kerklike, politieke en maatskaplike organe indien en/of in aansluiting daarby self
die verdure hervorming van kerk, samelewing en staat in word en daad nastreef. 
mistieke eienskappe vertoon. ${ }^{24}$ Die mistieke elemente van die pioniersbestaan van die binnelandse Boerepioniers is verder versterk en verdiep deur die gevaarvolle lewe op die grense van die Kaapkolonie en die twee Boererepublieke, die marginaliserende omstandighede waarin hulle as gevolg van Britse imperiale intervensies verkeer het, asook die fisieke oorlewingsbestaan waaraan hulle as gevolg van uiterste natuurlike faktore en die onstabiele verhoudings met binnelandse inboorlingstamme blootgestel was.

Die mate waartoe veral manlike pioniers in die geesteskultuur van die gereformeerde piëtisme onder die gevaarvolle omstandighede van die Kaapse grensdistrikte gebuk gegaan het, onder die druk van die wisselvallige Britse grensbeleid verkeer en die godsdienstige verwerking van hul omstandighede op 'n tipiese piëtistiese wyse in 'n eiesoortige pionier-etos gestalte gekry het, blyk uit ' $n$ brief van P. Daniël Bothma op 27 Junie 1801 aan sy vader Cornelis Bothma (Bothma 1801:1-4). Daniël Bothma skryf dat dit al meer as twee jaar is dat hy aan die trek en swerf met sy vee is, dat hy bo aan die Tarka en Bamboesberg-omgewing is, weg van sy plaas. Sy brief skryf hy vanaf Kromrivier terwyl hy daagliks op nuus wag om voor die vyand te vlug met die weinig besittings wat hy vanweë swart aanvalle oorgehou het. Die onseker bestaan wat hul van dag tot dag moet voer het tot gevolg dat hy nie weet wanneer hy weer na sy plaas sal kan terugkeer nie: '[m]aar wanneer dat wij weer vlijtighijt hebbe sal is onse alleen wijse alwetende God alleen bekent.' Ene Karel Erasmus is deur swart aanvallers vermoor. Vanweë die swart aanvalle is Daniël Bothma verplig om in die koue winternagte met sy oorblywende besittings te vlug: 'ja ik ken het met geen pen en ink uijtdrikke hoe en droevig toestant dat het geweest is.' Deur Gods ontferming oor hul toestand het hul wel weinig besittings oorgehou:

[D] og de Heere heeft ons tog altoos onder steunt al schoon dat dar soo veel onder ons het moete valle en sijnde door de moordenaars verloor de getrouwe Heere heeft ons dog niet schoon verlaat Schoon wij het verdient heeft want het de Heere Sijn wraak Swaart ten volle over ons uijt Gestort dan moes wij verdelg Sijn geweest maar in het medden van Sijn toorn dink hij nog aan sijn barmhartighijt. (Bothma 1801:1-4)

Hy voeg by dat hoewel die Here hul kasty, geen enkele haar van hul hoof kan val nie:

veel min Soo En Groote omstandigheijt Soo dat wij ons dan gewillig onder de hand des Heere nederlegge moet En verwagt onse hulp van den Heere alleen die door Sijn almagt Segge kan tot hier toe En nie te verder. (Bothma 1801:1-4)

Die mistieke geesteskultuur van die Boerepioniers in die binneland, het wyd onder sowel die vroue, mans as kinders van die Boeregemeenskappe voorgekom. In talle persoonlike piëtistiese tekste het dié pioniers hul mistieke ego-versugtinge in handgeskrewe gebedeboeke, persoonlike beskrywings van geestesvervoeringe, drome, visioene, asook manuskripte met geestelike liedere, gedigte en geestelike dagboekies, gevul met smartvolle beskrywings van dood, inboorlingaanvalle en allerlei katastrofiese gebeurtenisse uitgestort.

24.Veral die sterk fokus op die geestelike lewe, wat vanaf die vroeë dae van die Kaapse volksplanting na vore gekom het, het'n vrugbare bodem vir mistiek-getinte godsdienstige sentiment gebied. Kyk Simond (1699) en Faure (1733).

\section{Die mistieke piëtisme onder manlike gelowiges}

Die ego-beskrywings van vroue-pioniers op die binnelandse grense is deurspek met beskrywings van sielsveranderinge, verruklike waarnemings en sowel waarskuwende as gerusstellende gesigte. ${ }^{25}$ Die mistiek-piëtistiese dampkring waarbinne die pionierskinders opgroei, kultiveer ook onder hulle 'n sensitiwiteit vir drome en allerlei geestelike voorbodes. Maandag 16 Januarie 1837 teken eerwaarde Erasmus Smit aan dat sy seun, Salomon, in 'n betekenisvolle droom 'gesien' het hoe sy oom, Ignatius Maritz, in 'n sloot vermoor word en dat $\mathrm{H}$. Potgieter die swart aanvaller op sy oom doodsteek (Smit 1972:18-19).

Die ses- of sewejarige seun van Petrus Potgieter was daarvoor bekend dat hy vóórkennis van bepaalde gebeurtenisse ontvang het. Eerwaarde Erasmus Smit beskryf hoe hy met 'n rietjie op die water geslaan en vertel het dat sy vader besig was om onder die Matabeles te maai, juis terwyl sy vader toe 'n burger van die kommando was wat uit was om Silkaats te straf tydens die slag van Mosega en dat die Voortrekkers besig was om die Matabeles beslissend te verslaan (Smit 1972:19).

In sy eksemplaar van die Nadere Reformasie-skrywer Bernardus Smijtegelt se preekbundel Het Gekrookte Riet (1856), teken Jan Vorster ' $n$ droom van sy elfjarige seun Willem aan: in 'n droom sien die seun hoe die son en maan nie kon 'ooreenkom' nie - die son sê: 'Ik schijnt ligt met Plezier'; waarop die maan antwoord: 'Ik schijnt ligt met droefheid'; die maan: 'Ik schijnt heilig'; die son: 'Ik schijnt rechtvaardig'; die maan: 'Ik beteken Christus'; die son reageer: 'Ik is Christus zelf' ${ }^{\prime} 6$

Drome en visioene as vrug van die mistieke bevinding in die gereformeerde piëtisme, was nie tot vroue-gelowiges in die pionier-gemeenskappe beperk nie. In die pionierstyd, worstelend met die onseker toekoms van die binnelandse kerk, vertrek die geestelike leidsman van die Voortrek, Sarel Cilliers, in Oktober 1862 aan boord die Waldensian na die Sinodesitting in die Kaap. Kort voor die vertrek van die boot ontvang Sarel Cilliers 'n waarskuwende droom dat die reis nie voorspoedig sou afloop nie. Hy neem dit op hom om sy voornemende reisgenote wat nie gereed was vir die dood nie, te waarsku om liefs die reis te vermy. Maandag 13 Oktober het die Waldensian op die Aghulasrif naby Struisbaai op die rotse geloop. Sarel was een van die laaste passasiers om die boot te verlaat nadat hy en ds. G. van de Wall 'n gelofte afgelê het dat indien die Here hulle sou bewaar, hulle na hul aankoms op die strand aan God die nodige eer en dank sou betoon. Sarel het later vertel dat daar toe ' $n$ groot kalmte oor hom gekom het en dat hy die dood nie gevrees het nie. Sy lewe lank het Cilliers 'n sterk mistiek-bevindelike ingesteldheid vertoon (De Jongh 1987:256-257). In die Staats

25.Let veral op die tekste van pioniervroue uit die Trekboer- en Voortrekkerperiodes: Oordenkingsbundel van'n Van der Walt-vrou uit die omgewing van Colesberg (1797); Oordenkingsbundel van Hendriena Cesilea Kruger (1780); Oordenkingsbundel van Dorothea Gosen (c. 1820)

26.Dit is opvallend dat uitvoerige behandeling van die mistieke en die 'geheimnisvolle' beskrywing van die mistieke bevinding in Smijtegelt se werke voorkom, veral sy bekende (1857:586 e.v.); Maandagsche Katechisatiën (1837:270-271, vn. *). 
Courant der Zuid-Afrikaansche Republiek verwys Cilliers na 'n brief van ene mevrou Olivier, van Renosterberg, wat 'n goddelike openbaring gehad het waarin die heilige engele en 'de zalige zielen' in die hemel Psalm 99 en gesang 90 gesing het (Staats Courant der Zuid-Afrikaansche Republiek 1859, 22 April). Cilliers was voorts bekend vir sy voorkeure vir die bruidsmistieke geesteslewe. In 1853 maak hy melding van 'verskynings' aan hom van sy 'zielebruidegom':

Ditmaal in het zoete wezen van mijn ziele-Bruidegom is Hij mij verschenen. Tweemaal in en droom en eenmaal toen ik wakker was. Eenmaal als Leraar, toen ik zijn leerreede hoorde en ik ook kon zeggen: Hij leerde als machthebbende en niet als de schriftgeleerden. (Schoeman 1997:191 e.v.) ${ }^{27}$

Die gereformeerde volksleier en Staatspresident van die Zuid-Afrikaansche Republiek, Paul Kruger, beklee ook 'n prominente posisie in die kring van die gereformeerde piëtisme op die binnelandse grense en die mistiekbevindelike bedding waaruit dit opkom. Hy was 'n vurige leser van die Nadere Reformasie outeur Wilhelmus à Brakel, se dogmatiese werk Redelijke Godsdienst. Omstreeks die tyd van die inswering van M.W. Pretorius as president van die Zuid-Afrikaansche Republiek, in Januarie 1857, het Kruger 'n ernstige 'geestelike krisis' beleef. Die politieke onenigheid en twis wat die totstandkoming van die Republiek gekenmerk het, het hom in 'n geestelike stryd gedompel en tot wanhoop gedryf. In die eensaamheid van die Magaliesberge het Kruger uiteindelik rus vir sy geestelik-ontstemde gemoed gesoek. Na etlike dae is hy verswak van honger en dors, maar geestelik versterk, aangetref (Krüger 1961:56). Dié worsteling - soos Jakob by die Jabbokrivier - het by hom 'n godsdienstige verdieping tot gevolg gehad wat sy godsdienssin vir die res van sy lewe sou kenmerk. By verskeie geleenthede het Kruger nie gehuiwer om die groot Statebybel en 'Vader' À Brakel te voorskyn te haal om beswaarde gemoedere oor kerklike aangeleenthede te kalmeer nie (Vrystaatse Argiefbewaarplek GS 968, 42-45). ${ }^{28}$ Voorts was dit bekend dat Kruger, tydens sy bekleding van die amp van Kommandant-Generaal nie op kommando vertrek het, alvorens hy nie om leiding in die saak gebid het nie (Het Volksblad 1857, 10 Sept.).

Die mistiek-bevindelike geesteshouding met die meegaande sensitiwiteit vir drome, vóórkennis en visioene was 'n 'normale' deel van die lewenswyse van die afgesonderde Dopper-pioniers. Die koerant, Het Volksblad van 10 September 1857, berig oor die mistieke inslag by die gereformeerde pioniers:

Niets doende, houden zij zich onledig met zichtzelven te bespieden ... en zich verliezende in eenen maalstroom van verwachtingen, twijfelmoedigheden, zwartgalligheden', wagtende 'op wonderbare invloeden van omhoog (droomen, gezichtten, invallende schriftuurplaatsen).

27.'n Interessante 'stenografies-mistieke' teks, is dié van D. Strijdom, opgeskryf deu 'n vrou, Beatrix G. Nel (c. 1820).

28.Vir Paul Kruger se liefde vir À Brakel se werk, kyk Raath (2004:134-191); Vrystaatse Argiefbewaarplek GS 968. In die gereformeerde kringe van die grenspioniers is $\hat{A}$ Brakel selfs gebruik om ds. Andrew Murray se teologiese 'sentimente'; te toets, kyk Du Plessis (1920:129).

\section{Die mistieke ego-tekste van die pionier Francois Retief (1773-1838)}

\section{Histories-biografiese agtergrond}

Francois Retief (genealogiese verwysing: b4c7d1), gedoop 17 Oktober 1773, broer van die Voortrekkerleier Piet Retief, oorlede op 23 Julie 1838 in Natal, is op 30 November 1794 in die Paarl getroud met Martha Elisabeth Joubert (gedoop 28 April 1776). Sy was die dogter van Gideon Joubert en Anna Elisabeth Joubert. Na haar dood is hy op 24 Julie 1817 vir 'n tweede keer getroud met Martha Maria Maritz. Francois Retief was woonagtig te Voor-Sneeuberg, Graaff-Reinet. Hy sluit in middel-September 1836 by die trekgeselskap van Gert M. Maritz aan en trek saam na Natal (Visagie 2011:414).

Die ontberingsvolle lewe wat Francois Retief en sy familie moes deurmaak blyk uit sy dogter Anna Elizabeth Steenkamp (gedoop 05 Februarie 1797) se beskrywings oor hul trek na Natal, die druk wat die Voortrekkerpioniers daar moes deurmaak en kinderlike geloofsvertroue wat spontaan uit haar beskrywings spreek. Alhoewel die Voortrekkerleier G. Maritz en haar vader deel was van die voorste trekgeselskappe saam met Piet Retief, en Anna Steenkamp met die res van die familie agterna getrek het, was die omstandighede waarin Francois Retief en die res van sy familie hul op die trekpad bevind het, grootliks ooreenstemmend. Reeds op die eerste bladsy van haar herinneringskrif teken sy aan dat ten spyte van al hul swaarkry in die pioniersomstandighede 'hoe wel wij gelijt en beschermt weden door onse getrouwe God en vader, en deese swarige omstandigheden' (Steenkamp c. 1870:1). ${ }^{29}$ Sy meld terloops as een van die redes vir hul verhuising na Natal saam met die Voortrekkers hul behoefte om hul geloof suiwer te behou (Steenkamp c. 1870:1-2). In die nabyheid van die Drakensberg ontmoet sy en haar gesin weer die trekgeroep van Piet Retief met haar 'ou vader' Francois Retief en eerwaarde Erasmus Smit:

Daaroor was ons te danig bly, want die eerste kon tog ons wette uitvoer, en die laaste kon as predikant vir ons onderrig in Gods Woord, en Doop en Avondmaal bedien, sodat ons gereeld godsdiens gehad het. (Steenkamp c. 1870: 3 [vertl. A.W.G. Raath])

Sy voeg by: 'Elke Sondag, en elke aand was daar godsdiens, en dit het ons reis deur die woestyn waarlik aangenaam gemaak toe ons sien dat die Here ons nie verlaat het nie' (Steenkamp c. 1870: 3 [vertl. A.W.G. Raath]). Sy beskryf hoe, na afloop van die moorde te Bloukrans, die Trekkervroue by hulle aangekom, op hulle knieë geval en God gedank het 'voor de verlossing uijt de handen van den wreden tyran ... (Dingaan)'. Op 11 Februarie 1838 word haar oom, Piet Retief, saam met sy twee seuns en ander bloedverwante, te Dingaanstad vermoor (Steenkamp c. 1870:12). Op 10 Augustus 1838 word die trekgeselskappe waarvan Anna deel was, aan die Boesmansrivier aangeval:

Maar dank en prijs zijn wij schuldig aan den Heer die ons so wonderdadig uijt de handen onser tallose en bloet dorstige vijanden heef verlost en ons de overwinning schonk ... (Steenkamp c. 1870:12)

29.Die kopie geraadpleeg is van ongeveer 1870. Dit is egter bekend dat dele daarvan elders reeds in 1843 aangeteken is. 


\section{Francois Retief se mistiek-piëtistiese oordenkings- en liedboek}

Jesus-gesentreerde bruidsmistieke tendense in Francois Retief se ego-teks: Retief se handgeskrewe teks bevat prominente elemente van die gereformeerde piëtisme op die binnelandse grense: tekens van die bruidsmistiek, die bevindelike geloofsweg wat die gelowige bewandel, die gelowige se stryd op aarde in die spanningsveld tussen hemel en hel en elemente van ekstase van die gelowige se vereniging met God.

Die mistieke vereniging met Christus vorm 'n fokuspunt in Francois Retief se ego-teks. In 'n gedig wat bedoel was om gesing te word op die melodie van 'Ziele zúgt om voor Jesus te leeven; Stem: Op mijn Ziel, of: Ach! Was soll ich; of: Als een uitgestorte balsem', lui vers 2:

\section{Jesú, toon mij úw genade \\ Neem mij in uw liefde schoot, \\ Als bevrijd van alle nood! \\ Ban en drijft ook al het quade \\ uit mijn hert, dat ik mij, Heer, \\ Schikke gantsch tot úwer Eer.}

Die derde vers spreek van die tipiese Middeleeuse bruidsmistiek:

Kúst mij eenmaal, grote Minnaar,

Heilig met úw liefde mond,

Neem mij in úw heilverbond

Ach! mogt ik úw schoonheid in haar

glants aanschoúwen, dat ik stof

vond, om ú te zingen lof. ${ }^{30}$

In 'n piëtistiese gedig, 'De ontd. Sond. - soekt den Heere bij alle gelegentheiden en wel des morgens ontwaken. Stem hoe schoon ligt ons de morgen ster', word die versugting na eenwording met Jesus in Sy woning verwoord (v. 6):

\footnotetext{
Kom dan o jesú morgen Son

ontslúijt úw volheids liefde bron

Verligt mijn Zielen oogen

dat ik bij 't morgen ligt úw ligt

Aan schoúw en heylig mijn gesigt

Tot úw verhef om hoge

och toon hoe schoon

gij o koning in úw woning

Zijt en heerlijk

En voor al úw volk begeerlijk.
}

Op die melodie van Psalm 42 verwoord vers 3 'n Jesusgesentreerde minnesang ('Een súkkelende Ziele Bit om Versekerings van Zijn Staat') die hunkering om met Christus verenig te lewe:

Jesú gun mij dat uw goedheid

Send alleen een straaltje neer

dat ik eenmaal uwe soetheid

Smaak en noem ú mynen Heer

Ach omhels mijn bange ziel

grypse neemse tot úw diel

Jesú neemt mij met ontfarme

in ' $\mathrm{u}$ goedheids liefde armen.

30.In die kantlyn staan teenoor die vers aangeteken ' $D$. Malan', waarskynlik verwysend na Francois Retief se jonger suster, Anna Aletta Retief (gedoop 19 Jan. 1777), wat op 12 Mei 1793 getroud is met Daniël Gerhardus Malan (gebore 19 Junie 1772) burger van Stellenbosch, wat op 29 Maart 1837 oorlede is.
Die bevindelike geloofsweg: Die ingesteldheid van gelowiges in die dampkring van die geloofsbeoefening van die Nadere Reformasie, is gerig op die ondervindelike hetsy van Gods verlating hetsy van sy reddende almag. In Francois Retief se ego-verse is dit nie anders gestel nie. Die hunkering na die ervaring van Gods heil in Jesus Christus stort hy uit in die verlange om Jesus se nabyheid te ervaar. In vers 2 van 'n gedig spreek hy dié verlange soos volg uit:
'k kan met mijn verstand besinnen
dat al ' $t$ heyl in Jesus is
En 't onheijl in zijn gemis
maar mijn hert is koudt van binnen
door Een Vadsig dúf en doot
Schoon ik niet gevoel mijn nood.

In vers 4 bid hy om Jesus se goedgunstige nabyheid te ervaar:

O! heer Jesú ligt en leven
sonne der geregtigheid
toon mij úw goedgunstigheijd
Wilt dog Een herte geven
dat vermoeijt is en belaan
om tot uwen troon te gaan.

Die bevindelike sekerheid van die heil en verlossing in Christus staan deurgaans sentraal in Francois Retief se egoteks. Hy soek na die sekerheid van Gods teenwoordigheid, die sekerheid van Christus se nabyheid, om die ware boetvaardigheid te beleef en selfs die hunkering om die gelaat van Jesus te aanskou ('Súgtinge om gesigt van Jesú noodsakelykheidt. Stem: Rosemond die lag gedoken'):
Jesú wilt mijn hert Eens halen
úit het duystere tot úw ligt
flonker met úw liefde stralen
flúx op mij dat ik 't gesigt
Eerst op uw Schoonheids glans
regt gevestigt hebben gans.

In die spanningsveld tussen hemel en hel: Die verlange na die ewige rus by God en die stryd teen aardse bande en knellinge kom besonder sterk in Francois Retief se ego-teks na vore. ' $n$ Hele gedig is aan die aardse stryd en versugting om daarvan bevry te wees, gewy. In die gedig 'Belijdenis en súgtinge - Van eene toestemmende - om van alle hinder Palen bevryd te worden. Stem; Augustus ging Eens', spreek verse 1 en 5 van die bindingskrag van die Satan en die wêreld:

Vers 1:
' $\mathrm{k}$ Sie door 's hemels hoge goedheid
dat mijn siel in satans rag
nog gebonden en geboeijt leijt
O! dat ik 't met indruk sag
Here woú ze al de koorden
die mij van ú trekken af
en mijn Siel op ' $t$ Eynd vermoorden
gans vergrúisen als het kaf.

Vers 5:

\footnotetext{
'k kan niet komen want de werelt haat mij in haar Strikken vast door haar scheijn-goedt Rondt bepereld maar hoe word mij die een last Sallen ' $t$ niet de sterke handen Van úw Soon verrigten heer
} 
Geeft dat ik mij om van banden los te zijn leg voor uw neer.

In vers 6 word die versugting aan die bevrydende krag van Christus verwoord:

$$
\begin{aligned}
& \text { Hoe zal ik tot Jesú vlugten } \\
& \text { door gebeden 't scheijd maar waan } \\
& \text { daar ik naulyks kan Súgten } \\
& \text { of ontlasten Eenen traan } \\
& \text { maar wie Sal mij 't bidden leeren } \\
& \text { is 't niet Jesú door mijn geest } \\
& \text { Laat ik mij dan tot u keere } \\
& \text { Jesú dat gij mij geneest. }
\end{aligned}
$$

Die gedig 'Wensch om tot Jesús te komen; Stem: Onze Vader', vang in vers 1 die hunkering om van die aardse bande bevry te wees in ' $n$ gevoelvolle gebed vas (v. 1):
Maakt mij O Jesú! los van d'aard,
Aan welk mijn hert nog is gepaard,
Rigt mij úit 't stof op tot úw throon,
Geeft toegang tot $\mathrm{u}$, dierb're Zoon,
Aah ziet mij Jesú, hoe ik teer,
Regt walg'lik leg, in Zonden nêer.

Vers 4 bid om krag om na Christus te gaan en met die gelowiges voor Gods troon te vergader:
O Liefste Jesús geeft mij kragt
verbreekt in mij der zonden magt,
zend úwen geest, dat die mij leid,
Door 't Smalle pad in d'Eeuwigheid;
Dan zal ik met úw heilge Schaar
Uw Zingen Lof, hier en hier naar.

Ekstatiese elemente van die vereniging met God: Die Gees van God dring sy hart tot God ('De Geb: Zond: word op het zien van Godts weerdigheid eerbiedig en bevende; Stem: O Heilig Zalig Bethlehem of: O: Heilig, heilig ligt': v. 5):

Uw, geest die nu mijn Hert bewerkt,

Doet mij gantsch innig tot ú Zugten,

Zo haast mijn oog úw hand bemerkt,

Die het niet kan nog wil ontvlugten.

Hy ervaar Gods rus (v. 8):

Het is nú, of mijn aangezigt

Bedekt word met rus, heilgewaden,

Terwijl den hemel met zijn ligt

Mij gantsch omschittert uit genaden.

Hy word oorweldig deur die majesteit van God (v. 11):

Het wonder van úw Majesteit

Bedruipt mijn oog en doet de beeken

ontspringen, zelfs mijn herte schreijd

op 't Zien van zoo 'n wonderteken.

Eie roem en grootheid verdwyn (v. 14):

Mijn Kniën buigen zig devoot

weleer zo ongeneigt tot buigen,

En 't Schijnt nú of mijn hoogmoed groot,

verdwijnt, en plotselik valt in duigen.

\section{Samevatting en gevolgtrekking}

Die inslag van die gereformeerde mistiek in die pioniersgemeenskappe van die Suid-Afrikaanse binneland was nie tot vroue-gelowiges beperk nie. Alhoewel minder dikwels, het die gereformeerde mistiek in die vorm van piëtistiese tekste ook onder manlike gelowiges in die binneland voorgekom. Die oordenkingsbundel van Francois Retief (1773-1838) is ' $n$ voorbeeld van ' $n$ mistieke egoteks wat tipiese eienskappe van die Jesus-gesentreerde bruidsmistiek vertoon - ' $n$ tendens wat tot die Middeleeuse mistiek teruggevoer kan word. Die temperende effek van die Nadere Reformasie op die mistieke belewenisse van gereformeerde gelowiges op die binnelandse grense vind by Retief neerslag in ' $n$ klem op die bevindelike geloofsweg in die geesteslewe van die gelowige, die versugting om van die aardse bande en beperkinge vry te kom, aan die bindingskrag van die Satan en die wêreld te ontkom en die vreugde om met Christus verenig te lewe.

Alhoewel Retief se ego-teks nie blyke gee van buitengewone geestelike ervarings in die vorm van drome, visioene en uiterste vorme van ekstase - soos in die geledere van die gereformeerde mistiek in sowel Nederland as op die SuidAfrikaanse voorposte dikwels voorgekom het nie - kom elemente van ekstatiese bevinding wel in sy piëtistiese geskrif na vore.

Retief se getemperde vorm van ekstase hou waarskynlik verband met 'n groter mate van outentiek-Calvinistiese gereserveerdheid vergeleke met meer dramatiese vergestaltings daarvan by ander gereformeerd-mistieke eksponente. Ten spyte van minder ekstaties-bevindelike beskrywings, is daar voldoende aanduidings van bepaalde vlakke van 'verhoogde self-bewussyn' - 'n mistieke bewussynsintensiteit wat in die afgesonderde en moeitevolle lewe op die voorposte nie vreemd was nie. In sowel Nederland as onder gereformeerde pioniers in SuidAfrika het die verhoogde vlakke van bewussynsintensiteit gereformeerde gelowiges 'bemagtig' om ten spyte van knellende en uitsiglose omstandighede 'n intense en blymoedige geloofslewe te voer. Die wederkerende verskynsel van gereformeerde mistiek in die vorm van mistieke piëtisme is aanduidend van die veerkrag wat die gereformeerde mistiek vertoon wanneer gereformeerde gelowiges teruggewerp word in omstandighede analoog aan dié van die pioniersgemeenskappe in die binneland.

\section{Erkenning Mededingende belange}

Die outeur verklaar dat hy geen finansiële of persoonlike verbintenis het met enige party wat hom nadelig kon beïnvloed in die skryf van hierdie artikel.

\section{Literatuurverwysings}

À Brakel, W., [1700] 1726, Redelyke Godtsdienst, In welke de Goddelyke Waerheden des Genaden-Verbondts worden verklaert, tegen allerleye partyen beschermt, ende tot de practyke aangedrongen: Als mede ... een verklaringe van de Openbaringe Johannes, deel 2, 10de druk, Hendrik vanden Aak, Rotterdam.

À Brakel, W., [1700] 1739, Redelyke Godtsdienst, In welke de Goddelyke Waerheden des Genaden-Verbondts worden verklaert, tegen partyen beschermt, ende tot de praktycke aangedrongen ..., deel 1, 14de druk, Hendrik vanden Aak, Rotterdam.

À Kempis, T., 1680, Eenige Tractaetjes ... Bestaende in Het Hof der Roosen: Het da der Lelien. De drie Tabernakelen. D Alleensprake der Zielen. En de Boetveerdige Tranenene, Johannes Wasteliers, Amsterdam. 
À Kempis, T., 1687, Navolginge Christi door Th A Kempis verrijkt met het vierde Boek, uit het Frans vertaalt door $A G$, Júriaen van Poolsúm, Utrecht.

Barnstone, W. (ed.), 2005, The other Bible: Ancient Scriptures: Gnostic Gospels, Dead Sea Scrolls, Visionary wisdom texts, Christian Apocrypha, Jewish Pseudepigrapha, Kabbalah, Harper Collins Publishers, San Franciso.

Bijl, W., 1981, Krachtdadige bekeering van Willem Bijl. Manuskrip. Gepubliseer as Krachtdadige bekering van Willem Bijl: W H Hazejager, Puttershoek.

Broes, P., 1904, De Peinzende Christen, of Bundel van Stichtelijke Gedachten voor de Eenzaamheid: Met eene Voorrede van I P Hasebroek, Hollandsch-Afrikaansche Uitgevers Maatschappij, Kaapstad.

Campbell, K.J. \& Zaleski, C., 1991, German mystical writings, Continuum, New York.

Crane, F. (ed.), 1974, The lost books of the Bible and the forgotten books of Eden, Meridian Books, Boston.

Bothma, J.D., 1801, Brief aan sy vader, Cornelis Bothma (27 Junie 1801). (Kopie in die versameling van A.W.G. Raath).

Brienen, T., 1978, Bevinding - aard en funktie van de geloofsbeleving, J.H. Kok, Kampen.

De Goede, E., 1868, Eene korte en eenvoudige beschrijving van den weg der bekeering dien de Drie-eenige Verbondsgod met mij gehouden heeft, door E. De Goede, scheepstimmerman te Doesbogh, 1845 (overleden 2 mei 1852), 2de druk, J.C. van Schenk Brill, Doesburg.

De Jongh, C., 1987, Sarel Cilliers, Perskor, Johannesburg.

De Korte, C., 1781, Brief van Cornelis de Korte, landman onder Mariekerke, in den eilande van Walceheren, geschreven aan zijne kinders, over den bekeeringsweg welken God met hen heeft ingeslagen, Dirk Schuuring, Amsterdam.

De Niet, C.A., 1997, '“Nu ken ik ten dele” - Voetius over de mystiek', Documentatieblad Nadere Reformatie 21(1), 55-66.

De Reuver, A., 1997, 'Een mystike ader in de Nadere Reformatie', Documentatieblad Nadere Reformatie 21(1), 1-54.

Du Plessis, J., 1920, Het Leven van Andrew Murray, Zuid-Afrikaansche Bijbelvereniging, Kaapstad.

Eckhart, M., 2009, The sermons and collations of Meister Eckhart, Kessinger Publishing, La Vergne.

Faure, A., 1733, 'Onderrig- en Oordenkingsbundel', ongepubliseerde manuskrip. (Kopie in die versameling van A.W.G. Raath).

Fokkert, J.B., s.a., Schrift van Jan Barte Fockert, geboren in het yaar 1721 den 10 yuly, manuskrip.

Gosen, D., c. 1820, Oordenkingsbundel, manuskrip. (Kopie in die versameling van A.W.G. Raath)

Hellenbroek, A., 1745, De Kruis Triomph van Vorst Messias, ofte Verhandelingen over het Lyden, Sterven en Begraven van den Heiland der Uitverkoren Wereld; den
Heere Jezus Christus. Volgens vereenstemminge der Vier Euangelisten, in deszelfs Heere Jezus Christus. Volgens vereenstemminge der Vier Euangelisten,
oogwit Verklaart, Toegepast en Gepredikt, Adrianus Douci, Amsterdam.

Heppe, H., 1879, Geschichte des Pietismus und der Mystik in der Reformierten Kirche, namentlich der Niederlande, E.J. Brill, Leiden.

Hermsen, H., 1757, De uitnemende kracht van Christus liefde, zichtbaar doorstralende in het ontdekken en overtuigen der ziele ..., Hendrik van Pelt en Adrianus Douci, Rotterdam, Het Volksblad, 1857, 10 September, n.p.

Krüger, D.W., 1961, Paul Kruger, deel 1 \& 2, Dagbreek Boekhandel, Johannesburg.

Kruger, H.S., c. 1780, 'Oordenkingsbundel', ongepubliseerde manuskrip. (Kopie in die versameling van A.W.G. Raath).

Langelaar, T.H.H., 1997, “"Krank van liefde" - de gelukzalige ongezondheid van Theodorus à Brakel', Documentatieblad Nadere Reformatie 21(1), 67-76.

Mahrholtz, W., 1919, Deutsche Selbskenntnisse: Ein Beitrag zur Geschichte der Selbstbiographie von der Mystik bis zum Pietismus, Furche-Verlag, Berlin.

McGinn, B., 1991, The presence of God: A history of Western Christian mysticism: Vol. 1: The foundations of mysticism: Origins to the Fifth Century, Crossroads, New York.

McGinn, B., 1994, The presence of God: A history of Western Christian mysticism: Vol. II: The growth of mysticism. Gregory the Great through the 12th century, Crossroads, New York.

McGinn, B., 1998, The presence of God: A history of Western Christian mysticism: Vol. 1II: The flowering of mysticism: Men and women in the new mysticism - 12001350, Crossroads, New York.

McGinn, B., 2005, The presence of God: A history of Western Christian mysticism: Vol. IV: The harvest of mysticism in Medieval Germany, Crossroads, New York.

Mense, W. \& Teuling, C., 1877, Zin en zaakrijk verhaal, of Bekeeringsweg, Wilhelm, Vrijhoeven-Capelle. Newton, J., 1764, Gods Genade en Vrijmagtig Albestuur, Marthinus de Bruyn,
Amsterdam.
Op 't Hof, W.J., 1987, Engelse Piëtistiese Geschriften in het Nederlands, 1589-1622, Lindenberg, Rotterdam.

Pamans, G., 1775, Egt verhaal van geestelijke bevindingen, Simon Clemen, Zwolle.

Proost, P., 1880, Jodocus van Lodenstein, J. Brandt \& Zoon, Amsterdam.

Raath, A.W.G., 2003, 'Eensaam in die Voortrekkergemeenskap: Askese en geloofsbelewing in die teologie van die Voortrekkervrou Susan (1799-1836)', HTS Teologiese Studies/Theological Studies 59(1), 121-150.

Raath, A.W.G., 2004, 'Covenant, Calling and Democracy: The foundations of Paul Kruger's political Theology', Studia Historiae Ecclesiastica XXX(2), 134-191.

Ravestijn, H., 1746, De Nazireer Gods tot den Heiligen Dienst Bevordert, volgens eene Zekere Ordere in den Loop der Bedieninge Bestiert, en Door eenige Proef-stukken aangaande de Agtbaarheit van Gods Woodt, en de Bevindelyke Sterkte van Godts Volk, Vooral in Tyden van Beproevinge, voorgeligt, uit Jer. XXIII. vs. 28. 29. en Ps. LXII. vs. 12, Adriaan Wor, en de Erve G. Onder de Linden, Amsterdam.

Retief, F., c. 1830, 'Oordenkingsbundel en Liedboek', ongepubliseerde manuskrip. (Kopie in die versameling van A.W.G. Raath).

Roestijne, A.v.D., 1766, Tot eer van God en ter gedagtenis van Adriaan van de Roestijne, geboren te Westersouburg den 16 december 1712, overleden den ... [nie ingevul - Raath] en te Westersouburg begraven den 28 april 1779. Manuskrip, 1766. Gemeente Argief Vlissingen, Argief Hervormde Gemeente Westersouburg. (inventarisnommer 68).

Schoeman, K., 1995, Die Wêreld van Susanna Smit 1799-1863, Human \& Rousseau, Kaapstad/Johannesburg/Pretoria.

Schoeman, K., 1997, 'Vroeë geskrifte deur Suid-Afrikaanse vroue, 1749-1865', SuidAfrikaanse Historiese Joernaal 36(Mei), 24-47.

Schürmann, R., 2001, Wandering Joy: Meister Eckhart's Mystical Philosophy, Lindesfarne Books, Great Barrington.

Simond, P., 1699, 'Uitgesproken aan de Kaap de Goede Hoop op Sondag 25 Januarie 1699, herhaal te Amsterdam op 17 Oktober 1706 - Die ware aanbidding en die ware aanbidders Leerrede oor Johannes 4: 23 \& 24: “Maar daar kom'n uur, en dit is nou"', ongepubliseerde preek. (Kopie, vert. A.W.G. Raath).

Smijtegelt, B., 1740, Des Christens Heil en Cieraat, P. Van Thol \& A.L. en M.H. Callenfels, 's-Gravenhage-Middelburg.

Smijtegelt, B., 1837, Maandagsche Katechisatiën naar het geloof van de Heidelbergsche Catechismus, H. Den Ouden, Amsterdam.

Smijtegelt, B., 1856, Het Gekrookte Riet of Honderd Vijf en Veertig Predikatien over Matth. XII: 20, 21, I.J. Malga, Nijkerk.

Smijtegelt, B., 1857, Een Woord op Zijn Tijd, of Zeven en Veertig Predikatien, naar Tijdsomstandigheden geschikt, en behelzende Trouwhartige Vermaningen en Opwellende Besturingen, om Zich onder Gods Slaande Hand te verootmoedigen en tot Hem in Christus te bekeeren ... Met eene Voorrede over de Bevindinge van de Werkingen des H. Geestes, van Cornelis van Velsen, DI. II. Nijkerk, I.J. Malga.

Smit, E., 1972, The Diary of Erasmus Smit, ed. H.F. Schoon, transl. W.G.A Mears, C Struik, Kaapstad. Staats Courant der Zuid-Afrikaansche Republiek, 1859, 22 April, n.p.

Steenkamp, A., c. 1870, 'Joernaal', ongepubliseerde Manuskrip. (Versameling A.W.G. Raath).

Strijdom, D., c. 1820, 'Oordenkingsbundel', ongepubliseerde manuskrip. (Kopie in die versameling van A.W.G. Raath).

Tauler, J., 1961, Predigten, vertl. G. Hoffman, Herder, Freiburg.

Van der Groe, E., 1838, Bekeeringsweg van Eva van der Groe, zuster van Theodorus van der Groe, in leven predikant te Kralingen. Door haarzelve beschreven, J. Van der Vliet Cz., Rotterdam.

Van der Spek, P.C., 1850, Een boek ter beschrijvinge van eenige zaken en eenige weegen die de Heere met mij gehouden heeft zo lighamelijk als geestelijke van mijn 7 de jaar af tot mijn 86 ste door mij Paulus Abrahamse v[an] d[er] Spek, gebooren onder Ruyven den 10 e Maart 1725 en thans wonende op Delfgaauw. Den 10 maart 1809 op het 86ste jaar mijnes ouderdoms. Paulus Abrahamse van der Spek. Gemeente Argief Delft.

Van der Walt, C., 1797, 'Oordenkingsbundel', ongepubliseerde manuskrip. (Kopie in die versameling van A.W.G. Raath).

Van Diesbach, J., 1770, Eenen Wandelaar naar den Heemel ..., Pieter Brouwer, 's-Gravenhage.

Van Lieburg, F.A., 1991, Levens van vromen: Gereformeerd piëtisme in de achttiende eeuw, De Groot Goudriaan, Kampen.

Van 't Spijker, W., 1989, 'Bronnen van de Nadere Reformatie', in T. Brienen, K. Exalto, J. van Genderen et. al. (reds.), De Nadere Reformatie en het Gereformeerd Piëtisme, pp. 5-51, Uitgeverij Boekencentrum, 's-Gravenhage.

Visagie, J.C., 2011, Voortrekkerstamouers 1835-1845, Protea-Boekhuis, Pretoria.

Vrystaatse Argiefbewaarplek: GS 968 (01 Jan. 1858 - 07 Mrt. 1858).

Vrystaatse Argiefbewaarplek (VAB): Goewermentsekretaris (GS) 968. 